\title{
下䪽骨骨折後の骨シンチグラフィによる検討
}

\author{
兵行忠・原義治一小泉 博 \\ 乃村洋右・石井保婎
}

\section{Clinical evalution of the healing process after mandibular fracture by bone scintigraphy}

\author{
Yukitada Hyo - Yoshiharu HARA - Hiroshi KolzumI \\ Yosuke Nomura - Yasuo Ishir
}

\section{は じめに}

近年, 交通諸機関の発達や, 雇菜の発㨁に伴い, 下顎 骨骨折が增加し複傕化する傾向を示している。

このように頻度の高い下䫇骨骨折の治䇻過程を判定す るのに現在，一般的にX線写真が用いられている。しか し，X線写真では，骨の Ca 量が30〜 50\%変化しないと 骨の陰影としてあらわれない, る. そのために骨折の治癒の判定を早期に，しかも確実 に行う方法が種々検討されてきた。

先にわれわれは，下顎骨骨移植症例に対して骨 Scintigraphy を用いて，その経時的な治痛過程を検討した $か^{3}$ ), 今回, 下顎骨骨体部骨折症例に対して同梯な検討 を行い，若干の知見を得たので報告する。

\section{検 査 対 象}

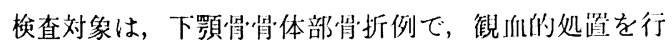
ったもの 9 例，非観血処谓例12例，計21例である，年潋 は，17歳より56藏までで，そのうち17〜25藏は15例， 25 蔵以上は 6 例であった。 また, その性別は, 男性18名, 女性 3 名であった（表 1 ）。

\section{方法}

${ }^{99} \mathrm{~m}$ Tc-diphosphanate ( ${ }^{99} \mathrm{~m}$ Tc-ethane-1, hydroxyl-1, diphosphonate, 以下 ${ }^{99 \mathrm{~m} T c-E H D P}$ と記す) 注射液 10 $15 \mathrm{mCi}$ を正中肘录挀に注射し，約 3 洔間後にシンチカ

京都大学医学部口腔外科学教室（主任：小野尊睦教 授)

Department of Stomatology, Faculty of Medicine, Kyoto University (Chief: Prof. Takatoki Ono)

受付日：昭和 54 年 2 月 14 日
表 1 症例

\begin{tabular}{|c|c|c|c|c|}
\hline Case No. & Name & Age & Sex & Treatment \\
\hline 1 & & 18 & $\mathrm{M}$ & Open \\
\hline 2 & & 17 & $\mathrm{~F}$ & Open \\
\hline 3 & & 18 & $\mathrm{M}$ & Open \\
\hline 4 & & 18 & $\mathrm{~F}$ & Open \\
\hline 5 & & 20 & $\mathrm{M}$ & Open \\
\hline 6 & & 20 & M & Open \\
\hline 7 & & 22 & $\mathrm{M}$ & Open \\
\hline 8 & & 23 & $\mathrm{M}$ & Open \\
\hline 9 & & 26 & $M$ & Open \\
\hline 10 & & 20 & $M$ & Closed \\
\hline 11 & & 21 & $\mathrm{M}$ & Closed \\
\hline 12 & & 21 & M & Closed \\
\hline 13 & & 22 & M & Closed \\
\hline 14 & & 24 & $\mathrm{M}$ & Closed \\
\hline 15 & & 24 & $\mathrm{M}$ & Closed \\
\hline 16 & & 35 & $\mathrm{~F}$ & Closed \\
\hline 17 & & 36 & $\mathrm{M}$ & Closed \\
\hline 18 & & 38 & M & Closed \\
\hline 19 & & 43 & $M$ & Closed \\
\hline 20 & & 46 & $M$ & Closed \\
\hline 21 & & 56 & $\mathrm{M}$ & Closed \\
\hline
\end{tabular}

メラにて骨 Scintiphotoを报影し，得られた Scintigram

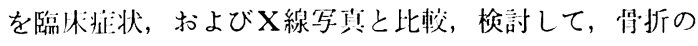
治㺄の過程を微察した。

結

果

受俉 5 日目の症例では, 骨折部位における RI の取り 込及呈は軙度に認められた（写真 1 ）。

受倠後 1 か月半の症例では, 骨折部の RI の集積は非 常に強く認められるようになった（写真 2 ). 


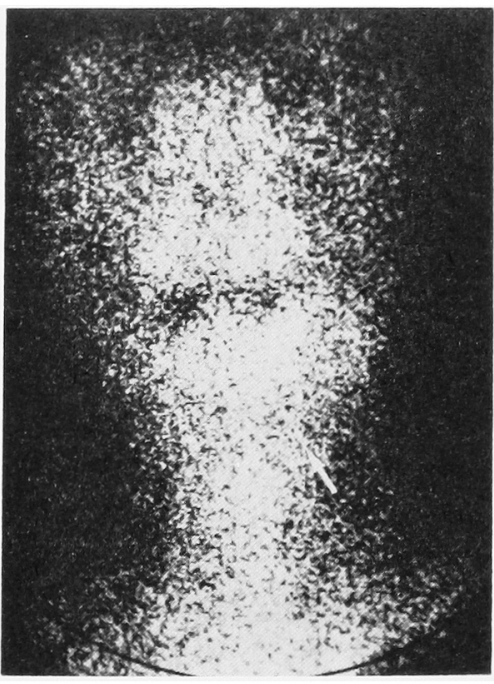

写真 1 受伤後 5 日目の骨 Scintigram 骨折部 ノ)に柽度な RI の取り込みが見られる。

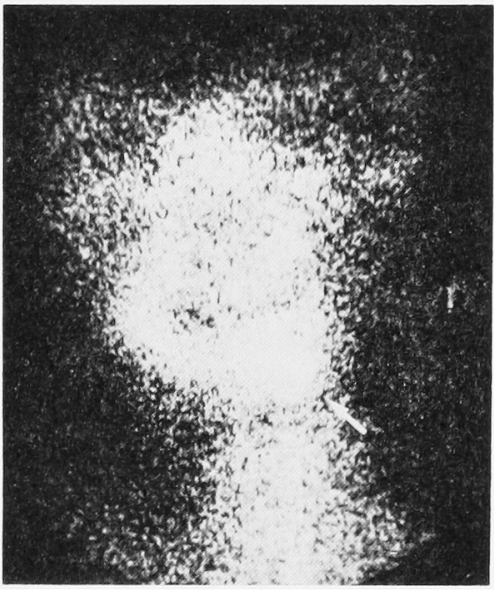

写真 3-a 3 か月後の骨 Scintigram 骨折部 ノ）の RI の uptake はやや減少を示 才。

受傷 3 か月を経過した症例では，X線写真で骨折線は いくぶん不明膫になるが，骨 Scintigraphy でも阑所に 身箖の減少便向が見られた（写真 3-a,b）.

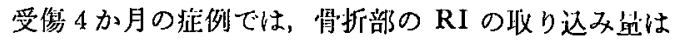
やや減少した (写真 4 ).

受傷 7 か月の症例では，X線写真で骨折線はほぼ消失 しているのに対して，骨 Scintigraphy で RI の取り込 み量は軽度ではあるか゚いまだ認められた（写直 5-a,b).

受傷後 1 年 4 か月の症例では、X線写真で骨折線の存 佂は認められず，完全に骨癒合がなされているようであ るが，骨 Scintigraphy では骨折部に軽度ではあるが集

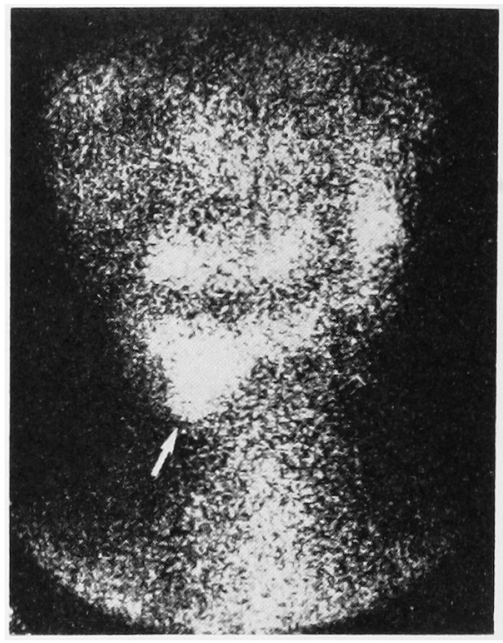

写真 2 受㩐後 1 か月半の骨 Scintigram 骨折部ぐに RI の取り込み量少增加し peak に達する。

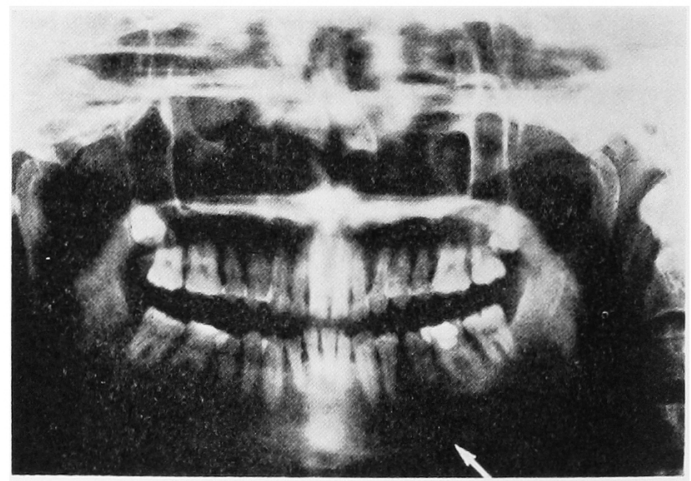

写真 3-b X 線写真で骨折線 (グ) はいくふん 不明瞭になる。

槕を認めた（写真 6-a, b).

受傷 1 年半を経過した症例では，骨 Scintigraphy で 正常骨と同様な集積を示すようになった（写真 7).

\section{考察}

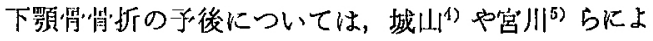
り战告されている。また，少折の治瘾の機忶に関して

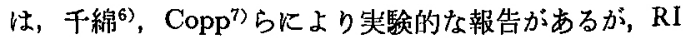
を用いて骨折の手後の経時的な钼察や治瘾の過程につい ては，松井 ${ }^{8)}$ による ${ }^{85 \mathrm{~m} S r}$ を用いた実験的な検討や，大

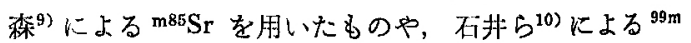
Tc-phosphates による長管骨”骨'折の観察を見るが，下顆

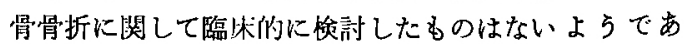
る. 


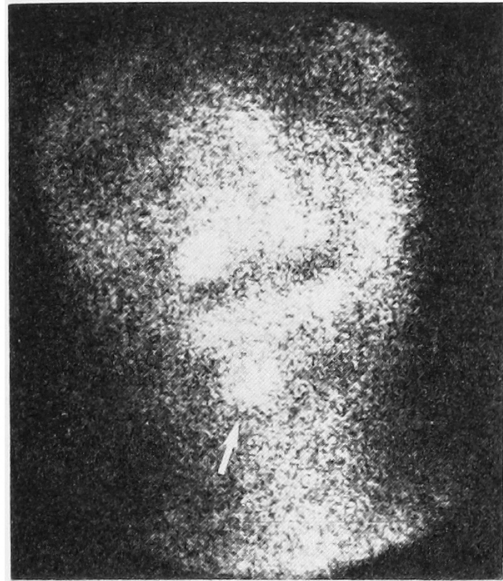

写真 44 か月の症例の骨 Scintigram 骨折部(ノ) の RI の uptake は 3 か月の症例に 比してなお軽度となる

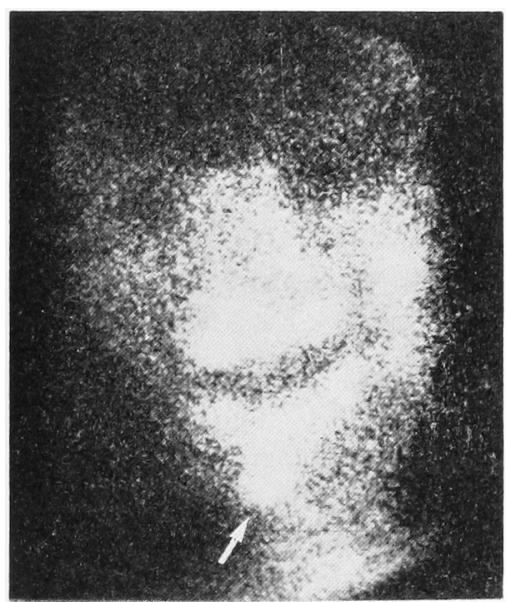

写真 5-a 受場 7 か月の骨 Scintigram 骨折部 ノ）に毦度な RI の uptakを認める。

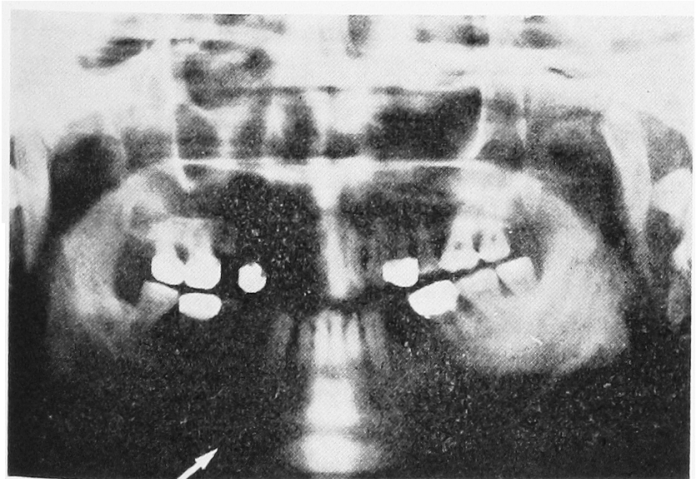

写真 5-b X線写真で骨折線（ノ）は注ほ消失する.

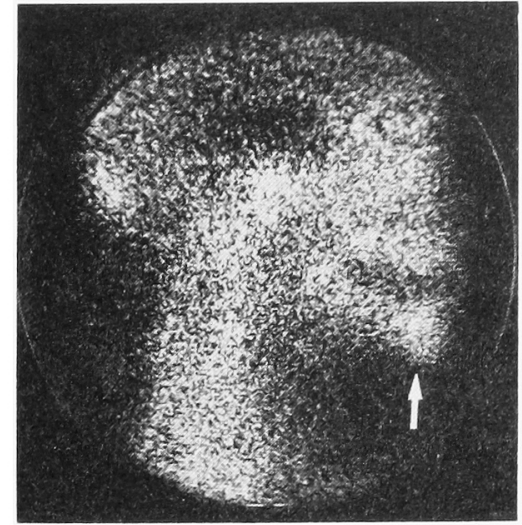

写真 6-a 1 年 4 か月後の骨 Scintigram 骨折部 (ノ) に軽度な RI の uptakeを認める。

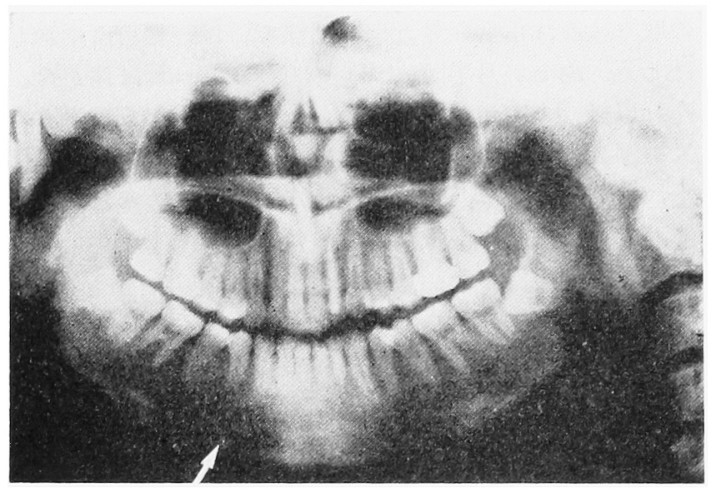

写真 6-b 1 年 4 か月後の X線写真 完全な骨捻合の像を呈する(ノは骨折線).

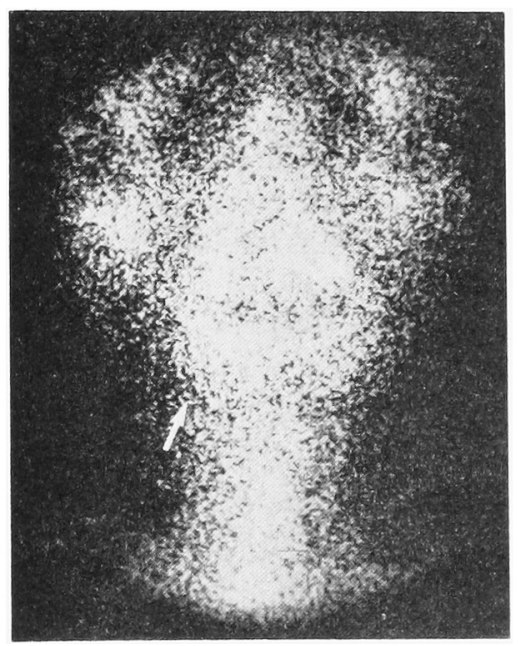

写真 71 年半後の骨 Scintigram 正常骨と同様な uptakeを示す( 
また，骨折の治疮の判定は，一般にX線写真が用いら れているが，X線写真では骨の Ca 量が30〜 50\%変化し ないと骨の陰影としてあらわれず1,2)，骨性㿑合がある 程度進行しないとX線上判然としないという ${ }^{11)}$ 久点を有 し，したがって臨床上，仮骨瘉合期の判定はある程度経

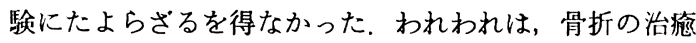

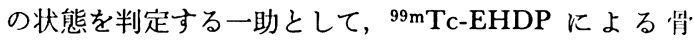
Scanを行った.

大森 ${ }^{92}$ の長管骨の経時的な観察によると, 正常な省癒 合を行ら症例では，受傷すぐには集䅡の差が正常骨とは ほとんど認められず，骨瘉合の開始とともに強い集䖽を みるよらになり，12週で RI の取り込み量は peakにな り，その後漸次減少していくと述べている，また，山本 12)の下顎骨骨折の観察では, RI の取り込み量が peak に達するのは 4 週で，その uptake ratio は正常な集秒 を 1.0 とすると 2.0 になると述べている.

今回のわれわれの観察では，受偒 5 日日で局所の RI の取り込みは正常な筒とほぼ同栚で，以後集稍は增加し はじめ, 約 1 か月半頃に RI の集䀧は peakに道した。 それ以後 RI の集䅡は軽度になり，約 1 か年を経過した X線写真上で骨折線が認められなくなった症例において も，なお骨折部に RI 取り込みが軽度に認められ，完全 に RI の取り込みが正常となるのは受賃後 1 か年半を経 過した症例であった。

骨折後から 1 か月半までの間に RI の取り込み量が急 激に増加するのは，仮骨の形成がこの時期に最も活発に 行われることによるものであろう．仮骨の生物学的形 成，すなわち骨基質の增大に伴う骨塩沈着が增加すれ ば, surface exchenge および recystallization も增加し ていき，仮骨基質に沈着する新しい骨塩形成は， surface exchenge と recystallization のいずれが多いかを決定す ることは困難であると伊滕 ${ }^{13,14)}$ は述べている。

尚折の治撚の過程に扎いて，仮骨の形成は坐要な条件 であり，骨塩部の新生仮骨における骨塩供給の主体は全 身の血行性によるものであると太田 ${ }^{15)}$, 岩間16)は報告し ている。 また，Lexer ${ }^{17)}$ は外骨膜への血管供給が筒折治 㾑に最も必要なものであると述べている，以上により， 仮筒の形成には血管系が大きく関与するものと考えられ る.

骨折の治癒は，さらに類骨または類軟骨組䄉を経て層

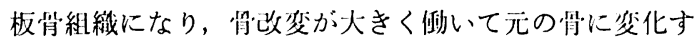
るものであるとされている18).

したがって，骨折の治㗪の状態を判定するために忪 井 $^{8)}$ は，仮骨の量とともにRI の取り込み量は增加し， 仮骨量が peak に達した時には RI の取り込み量も peak になり，仮骨显の減少とともに RI の取り込み楒 は下降し， RI の取り込み员と仮骨形成との間にはなな んらかの相関関係があると考えられると逨べている。

われわれは，99mTc-EHDP を用いた骨 Scan により，
受伤後より骨折部の仮骨形成が活発になり， RI の取り 込み量が peak を過ぎる 1 か月半以降は，仮骨量の減少 による治痛の過程に入ったものを示すものであろうと考 えた。

\section{む す び}

${ }^{99} \mathrm{~m}$ Tc-EHDP により, 下䫇骨骨体部骨折21例に対し て経時的に骨 Scanを行った。

（1） RI の取り込み量は，受賃直後より1か月半まで に急激な增加を示し，受賃 1 か月半で peak に達し，以 後減少傾向を示した。

（2）X線写真上で骨折線が認められなくなった受傷後 1 か年を経過しても，骨 Scintigraphy ではなお局所に RI の集積が軽度に認められ， RI の取り込み量が正常 となるのは，受傷後 1 か年半を経過した症例であった，

（3）下碩骨骨折に拈ける治癒は，受鹪後より仮骨・の形 成が盛んに行われ，1 か月半でpeak に達しても，約 1 か年半までの閌 active な省の代謝が行われていると推 察された。

本論交の要旨は，昭和50年 9 月 27 日，第20回日本口腔 外科学会ならびに昭和 51 年 10 月 10 日，第 21 回日本口腔外 科学会に拈いて発表した。

稿を終わるに当たり，終始こ留切なこ指導を晹わった 小野尊陸教授に深甚なる謝意を表します。な拉䜍に際 して, 多くのこ援助を下さった口腔外科教室, 各先生方 に深钎致します。

\section{引用 文 献}

1) Edelstyn, G.A., et al.. The radiological demonstration of osseous metastases, Experimental observation. Clin Radiol 18: 1581967.

2) Hengst, W., et al.: Tumorfrük-lokalisation im Skelet mit Strontium 85. Fortshr Rontgenstr 106: 7281959.

3) 石井保雄, 他: 下顎骨々移植後に扣ける骨シン チとX線像との臨床的検討。日口外誌 $23: 29$ 1977.

4）城山测彦，他：最近 5 ケ年間のわが教室におけ る颚骨々折の臨床的钼察。透科医学 $21: 687$ 1958.

5）宮川喜光，他：靧骨々折に関する臨床的，統計 的锶察。口病誌 $24: 3891957$.

6) 千綿秀鹰: 骨折治沼過程の組織化学 Microradiography ならびに Tetracycline Labeling に 上る研究。四学 $57: 81969$.

7) Copp, D.H., et al.: Studies on bone fracture healing. J Nutrition 29 : 2611945.

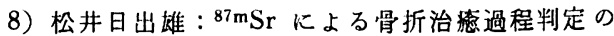


基礎的研究。曾学 59: 3861971 .

9) 大森苝婎：あすへの整形外科展抂. 金原出版, 東京, 1972，292頁.

10) 石井勝美, 他: Bone-Scanning with Tc-99m phosphates (抄). 核医学 12: 2131975.

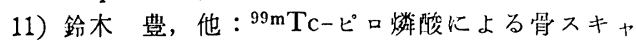
ソ. Med Post Graduates 11: 621973.

12）山本逸雄: ${ }^{99} \mathrm{mTc}$ 標識りン酸化台物による骨シ ンチグラフィの臨休的検討（IV）骨折ならびに 骨移植について。 日本医放会誌 38 1978. （投 稿中）

13）伊藤邦彦：放射性同位元素 ${ }^{45} \mathrm{Ca}$ に上る骨折の 研究. 日医大誌 $19: 11451952$.

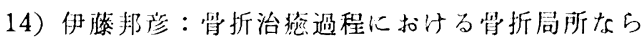
びに具格系にみられる ${ }^{45} \mathrm{Ca}$ 盐の移行と再分配 の変化について。 日医大誌 $24: 431957$.

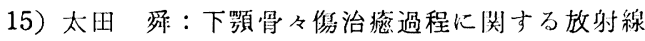

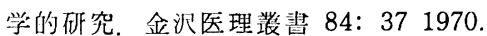

16）岩間升：骨借治崅に関与る放射線学的矿究 金沢医理媵書 86：61 1970.

17) Lexer, E.: Lehrbuch. d. allg. chirurgje zuns. Gebrauche fur Arzte. u. studierend. 20 Aufi. 2: 661934.

18）三木威勇治：整形外科学入門。南山堂，東京， 1965，230頁. 